Original article

\title{
Evaluation of cervical mucus and reproductive efficiency of seasonally anovular dairy goats after short-term progestagen-based estrous induction protocols with different gonadotropins
}

\author{
Jeferson F. Fonseca ${ }^{\mathrm{a}, *}$, Joanna M.G. Souza-Fabjan ${ }^{\mathrm{b}}$, Maria Emilia F. Oliveira ${ }^{\mathrm{c}}$, Renata C. Cruz ${ }^{\mathrm{d}}$, \\ Luciana V. Esteves ${ }^{\mathrm{b}}$, Maria Pia S.L. Matos de Paiva ${ }^{\mathrm{e}}$, Felipe Z. Brandão ${ }^{\mathrm{b}}$, Antônio B. Mancio ${ }^{\mathrm{d}}$

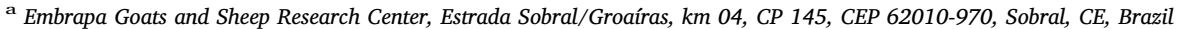 \\ b Faculty of Veterinary Medicine, Fluminense Federal University, Av. Vital Brasil Filho, 64, CEP 24230-340, Niterói, RJ, Brazil \\ ${ }^{\mathrm{c}}$ Department of Preventative Veterinary Medicine and Animal Reproduction, School of Agricultural and Veterinary Sciences, São Paulo State University, Via de acesso Prof. \\ Paulo Donato Castellane s/n, CEP 14884-900, Jaboticabal, SP, Brazil \\ d Department of Animal Science, Viçosa Federal University, Av. P.H. Rolfs, s/n, CEP 36571-000, Viçosa, MG, Brazil \\ e Capril Sanri, Av. Constelações 385/242, Vale dos Cristais, CEP 34000-000, Nova Lima, MG, Brazil
}

\section{A R T I C L E I N F O}

\section{Keywords:}

AI

Anestrus

Cervical mucus

Estrous induction

Goat

\begin{abstract}
A B S T R A C T
The use of three different gonadotropins was tested for estrous induction in dairy goats during the non-breeding season. All does received an injection of $30 \mu \mathrm{g}$ of d-cloprostenol and intravaginal sponges containing $60 \mathrm{mg}$ of medroxyprogesterone acetate (MAP) for 6 d plus 20 IU of porcine FSH (pFSH), 200 IU of eCG or 250 IU of hCG $24 \mathrm{~h}$ before sponge removal. In Experiment $1(\mathrm{n}=24)$, ovarian ultrasound parameters were recorded and cervical mucus was evaluated daily for $5 \mathrm{~d}$ after sponge removal or until ovulation. In Experiment $2(\mathrm{n}=80$ ), reproductive efficiency of artificially inseminated or naturally mated does was assessed. The mean interval from sponge removal to ovulation $(73.5 \pm 23.7 \mathrm{~h})$, number of ovulations $(1.6 \pm 0.7)$ and ovulatory follicle diameter $(7.2 \pm 0.8 \mathrm{~mm})$ did not vary $(\mathrm{P}>0.05)$ among the three groups. At ovulation, cervical mucus had crystalline-striated to striated $(22.2 \%)$, striated to striated-caseous $(72.2 \%)$ and striated-caseous to caseous (5.6\%) appearance. The largest follicle diameter was greater $(\mathrm{P}<0.05)$ in does with crystalline $(6.7 \pm 1.4$ $\mathrm{mm})$, crystalline-striated $(7.2 \pm 1.1 \mathrm{~mm})$ or striated $(7.3 \pm 1.3 \mathrm{~mm})$ mucus than in those with striated-caseous $(5.3 \pm 1.4 \mathrm{~mm})$ or caseous $(4.5 \pm 1.1 \mathrm{~mm})$ mucus. Percentage of animals exhibiting estrus $(92.5 \%)$ and conception rate $(60.8 \%)$ were similar $(\mathrm{P}>0.05)$ among the three gonadotropins groups. Results of this study support the use of eCG (200 IU), hCG (250 IU) and pFSH (20 IU) for the estrous induction protocols in dairy goats during the non-breeding season. Cervical mucus evaluation can be used as an additional method to determine the optimal time for artificial insemination in goats.
\end{abstract}

\section{Introduction}

In southeastern Brazil, commercial dairy goat operations using specialized breeds constantly require controlled reproductive management in order to obtain sufficient amount of milk throughout the year. The most frequently used estrous induction protocols are based on the use of equine chorionic gonadotropin (eCG) and intravaginal progesterone- or progestagen-releasing devices [1]. During the non-breeding season, gonadotropin is usually injected one day before the end of progestagen treatment to stimulate ovarian follicular development $[2,3]$. eCG is a glycoprotein secreted by trophoblast cells in the mare during gestation. The dual (FSH- and LH-like) activity, long half-life and widespread availability make it a convenient hormone for estrous induction treatment in goats. However, eCG is the most heavily glycosylated glycoprotein hormone and, from the first treatment, it may induce the production of anti-eCG antibodies [4]. These antibodies may delay the preovulatory LH surge and ovulation leading to poor fertility of the eCG-treated females [5].

It is necessary to circumnavigate the effects of such an immunological reaction to the gonadotropic agent by using an alternative hormone in order to maintain the efficiency of estrous induction programs for artificial insemination (AI). However, there is a paucity of literature on the use of other gonadotropins for estrous induction in goats. Human chorionic gonadotropin (hCG) with a potent LH-like

\footnotetext{
* Corresponding author.

E-mail address: jeferson.fonseca@embrapa.br (J.F. Fonseca).
} 
activity has been used in estrous and ovulation synchronization protocols in domestic animals [6]. This hormone has a long half-life of approximately $39 \mathrm{~h} \mathrm{[7]} \mathrm{and,} \mathrm{although} \mathrm{there} \mathrm{are} \mathrm{only} \mathrm{a} \mathrm{few} \mathrm{reports} \mathrm{on} \mathrm{its}$ effects in goats, the results obtained were very encouraging: hCG stimulated follicular development and induced fertile estrus in the early postpartum period [8], it resulted in estrous behavior and ovulation in all treated, sexually mature goats in the breeding season [9] and in the $61.1 \%$ conception rate after natural mating [2].

Follicle-stimulating hormone (FSH) is a primary promoter of antral follicular growth and has a short half-life of about $10 \mathrm{~h} \mathrm{[10].} \mathrm{Although}$ FSH is widely used in superovulatory treatments, there is no report of its use for estrous synchronization in goats. In sheep, when combined with progesterone pre-treatment, porcine FSH was effective in the synchronization of estrus and ovulation [11], and its administration was associated with high pregnancy rates $[66 \%$ and $79 \%$ using long(12-day) or short-term (5-day progesterone treatment) protocol, respectively] [12].

It is known that the macroscopic appearance of cervical mucus changes from crystalline to caseous from the onset to the end of behavioral estrus [13] when ovulation normally occurs [14]. However, there are presently no data on the relationship between changes in cervical mucus and antral follicular dynamics that would allow for the prediction of the ovulation time in goats. We hypothesized that evaluation of cervical mucus could assist in determining the optimal time for AI in goats. Therefore, the aims of the present study were to: i) evaluate the use of hCG and pFSH as substitutes for eCG in estrous synchronization protocols; and ii) characterize the temporal changes in cervical mucus during various estrous induction protocols and their associations with ovulatory dynamics in dairy goats during the nonbreeding season.

\section{Material and methods}

\subsection{Location and experimental conditions}

This research project had been reviewed and approved by the Animal Care Committee of Fluminense Federal University (protocol 048/08), and was in compliance with the guidelines of the Brazilian Society of Laboratory Animal Science (SBCAL) that contain regulations on the use of experimental animals.

The present study was conducted from September to October and it utilized animals housed at two different locations. The first experiment (Experiment 1) was conducted in the rural area of Piau, MG, Brazil (latitude $21^{\circ} 35^{\prime} \mathrm{S}$, longitude $43^{\circ} 15^{\prime} \mathrm{W}$ and altitude of $435 \mathrm{~m}$ ). The second experiment (Experiment 2) was conducted both in Piau, MG, Brazil as well as in the rural area of Florestal, MG, Brazil (latitude $19^{\circ} 53^{\prime} \mathrm{S}$, longitude $44^{\circ} 25^{\prime} \mathrm{W}$ and altitude of $776 \mathrm{~m}$ ). In such conditions, the breeding season (period of shortening daylengths) is from March to June, the non-breeding season (period of lengthening daylengths) is from August to November, and the transitional period (period of relatively stable long daylengths) is from December to February [15].

A total of 104 dairy goats (15 Alpine, 38 Saanen and 51 Toggenburg), of eight months to five years old, were used in this study. Goats were kept in an intensive management system, and grouped according to physiological status and milk production in pens housing 10 to 12 goats each (2.5 to $3 \mathrm{~m}^{2}$ per animal). Goats were fed corn silage and Pennisetum purpureum K. Schum as forage, and balanced concentrate supplement (soy bean, corn and mineral nucleus based mixture). Nonlactating multiparous and nulliparous goats received daily rations of $0.5 \mathrm{~kg}$ of concentrate/goat (homemade mixture with $16 \%$ crude protein and $68 \%$ total digestible nutrients - (TDN) and $4.0 \mathrm{~kg}$ of chopped elephant grass/goat. Lactating goats received daily rations $1.5 \mathrm{~kg}$ of concentrate/goat (homemade mixture with $22 \%$ crude protein and $69 \%$ TDN) until the attainment of daily milk yields of $3 \mathrm{~kg} /$ goat plus $0.33 \mathrm{~kg}$ of concentrate for each additional $\mathrm{kg}$ of milk produced and $4.0 \mathrm{~kg} / \mathrm{goat}$ of corn silage. Mineralized salt licks (Salminas Goats ${ }^{\circledR}$, Nutriplan, Juiz

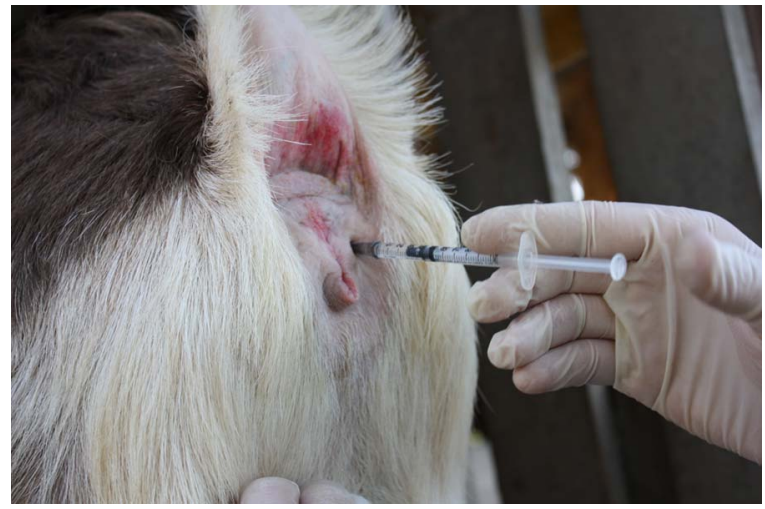

Fig. 1. Cloprostenol administration by latero-vulvar route. A $1 \mathrm{~mL}$ syringe coupled to a $0.7 \mathrm{~mm} \times 25 \mathrm{~mm}$ needle was used for each animal.

de Fora, MG, Brazil) and drinking water were available ad libitum.

\subsection{Experimental procedures}

Estrous synchronization was performed as described previously by our group $[2,16]$. All goats received intravaginal sponges containing $60 \mathrm{mg}$ of medroxyprogesterone acetate (MAP; Progespon ${ }^{\circ}$, Syntex S.A., Buenos Aires, Argentina) for $6 \mathrm{~d}$ as well as $30 \mu \mathrm{g}$ of d-cloprostenol (Veteglan , Laboratórios Callier S.A., Barcelone, Spain) administered by latero-vulvar route (Fig. 1) and a dose of gonadotropin (20 IU of porcine FSH (pFSH), 200 IU of eCG or 250 IU of hCG, i.m.) administered $24 \mathrm{~h}$ before sponge removal (Day 5 ).

In Experiment 1, nine nulliparous and 15 multiparous Toggenburg goats (nine lactating and six non-lactating) were allocated according to parity and lactation status, body weight (BW) and body condition score (BCS, range 1 to 5), into three subsets: (i) $\mathrm{pFSH}(\mathrm{n}=8$, BW: $47.8 \pm 15.0 \mathrm{~kg}$, BCS: $3.1 \pm 0.5$ ) receiving $20 \mathrm{IU}$ of pFSH (Pluset, Hertape-Calier, São Paulo, Brazil) i.m.; (ii) hCG ( $n=8$, BW: $47.9 \pm 13.9 \mathrm{~kg}$, BCS: $3.2 \pm 0.5)$ treated with 250 IU of hCG (Vetecor ${ }^{\curvearrowleft}$, Hertape-Calier, São Paulo, Brazil) i.m.; and (iii) eCG ( $\mathrm{n}=8$, BW: $48.0 \pm 13.5 \mathrm{~kg}$, BCS: $3.1 \pm 0.3$ ) treated with $200 \mathrm{IU}$ of eCG (Novormon $5000^{\circ}$, Schering Plough Animal Health, São Paulo, Brazil) i.m. as described earlier.

After MAP sponge removal, estrous behavior was monitored twice a day (06:00 and 17:00 h) with hand-controlled bucks to avoid penile penetration and the does were considered to be in estrus when they stood to be mounted. Cervical mucus appearance was evaluated twice daily for $5 \mathrm{~d}$, starting $12 \mathrm{~h}$ after sponge removal. A sterilized Collin vaginal speculum (lighted) was used to classify cervical mucus types using the 1-5 scale as follows: crystalline -1 (mucus completely translucent); crystalline/striated - 2 (mucus with some opacity but devoid of striation); striated -3 (evident striation within crystalline areas); striated/caseous - 4 (striation coalescing and no visible translucent areas); and caseous -5 (mucus appearing as a caseous mass with evident flocculation). Different types of cervical mucus observed in the cervical os and vulva of goats are shown in Figs. 2 and 3, respectively. Note that the diameter of the cervical os opening expands as the cervical mucus changes from crystalline to striated/caseous (Fig. 2).

Transrectal ovarian ultrasonography was performed by the same, experienced operator every $12 \mathrm{~h}$ from $24 \mathrm{~h}$ after sponge removal until ovulation. All examinations were conducted with a B-mode ultrasonographic scanner connected to a $6.5-\mathrm{MHz}$ transrectal transducer (Pie Medical Aquila Vet ${ }^{\circ}$, Campinas, Brazil). The transducer was fitted with a plastic rod that allowed external transrectal manipulation of the probe. All does were examined in a standing position; fecal pellets were removed and $20 \mathrm{~mL}$ of carboxymethylcellulose gel was injected into the rectum with a syringe prior to scanning. Ovaries were located as previously described [17], and the number, diameter, and position of 

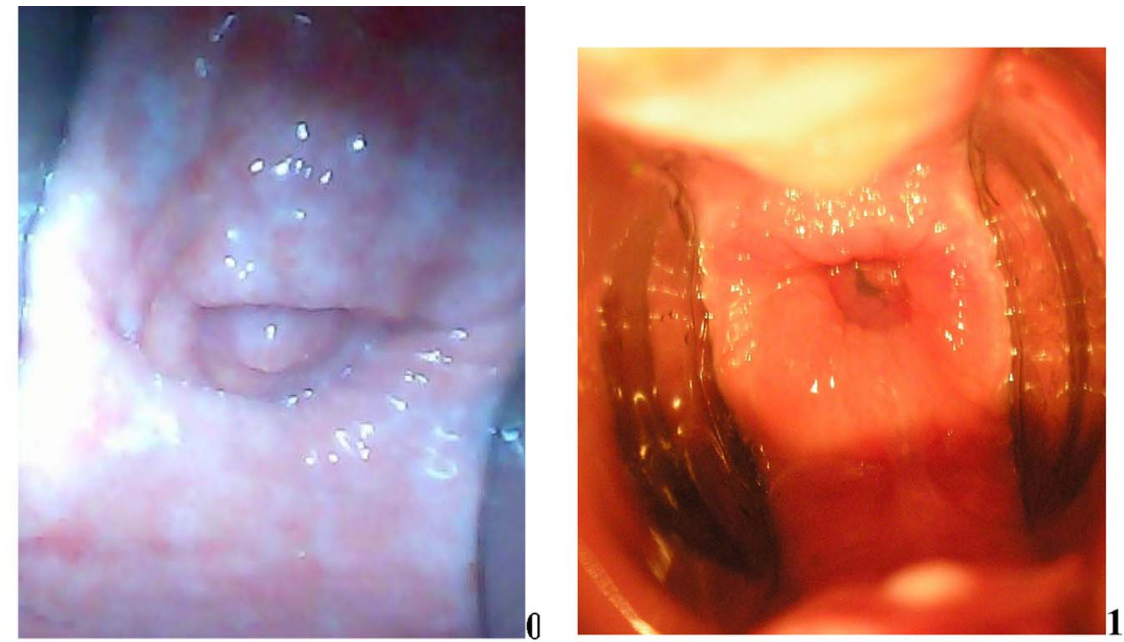

Fig. 2. Observations on the cervical mucus discharge in the cervical os of the goats. 0-no discharge, no estrus; 1-crystalline mucus; 2-crystalline/striated mucus; 3-striated mucus; 4-striated/caseous mucus; and 5 -caseous mucus. See the text for details of mucous categories.
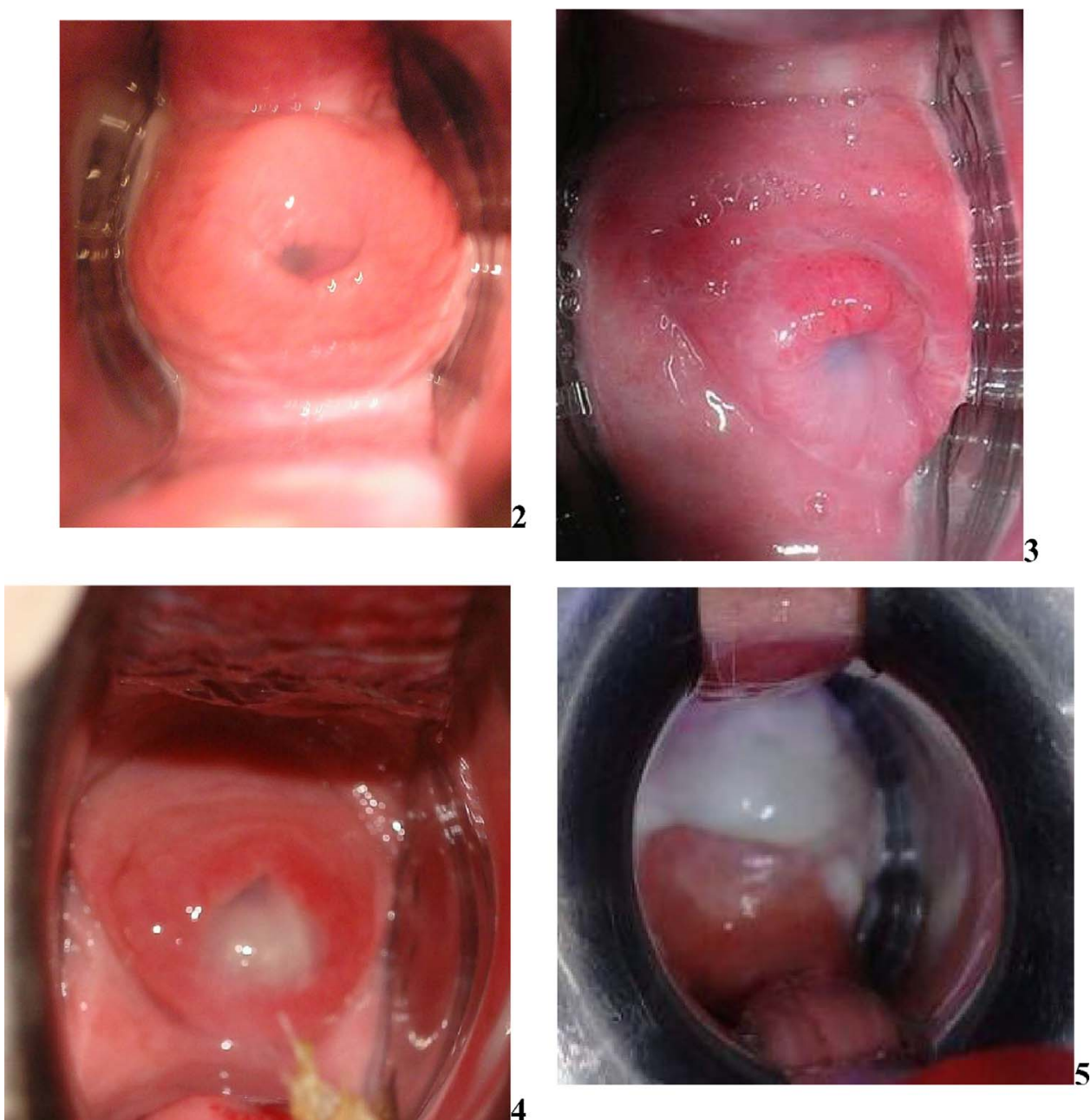

ovarian follicles $\geq 3 \mathrm{~mm}$ were recorded. The day of ovulation was defined as the day on which an identified preovulatory follicle(s) was no longer detected.

In Experiment 2, eighty multiparous dairy goats with at least seven months of lactation (15 Alpine, 38 Saanen and 27 Toggenburg) were grouped by milk production, breed, BW, BCS and breeding methods, and then similarly allocated to one of the following gonadotropin treatments: pFSH ( $=26$; BW: $45.1 \pm 14.9 \mathrm{~kg}$, BCS: $3.0 \pm 0.4$ ), eCG ( $\mathrm{n}=27$; BW: $45.1 \pm 12.4 \mathrm{~kg}$, BCS: $3.0 \pm 0.2)$ or hCG $(\mathrm{n}=27$; BW: $45.8 \pm 14.2 \mathrm{~kg}$, BCS: $3.0 \pm 0.4$ ). After MAP sponge removal, goats in estrus were either artificially inseminated ( $\mathrm{n}=22$ ), in a standing position [18], at $22-24 \mathrm{~h}$ after the onset of estrus or naturally mated ( $n=52$ ) by fertile bucks at the onset of behavioral estrus and then every $12 \mathrm{~h}$ throughout estrus. AI utilized commercial frozen/thawed semen with a minimum of $45 \%$ progressive motility and 3 spermatic vigor ( $0-5$ variation) from four bucks (two Saanen and two Alpine) aged 2-4 years, participating in the Brazilian progeny test - CapraGene (donated by Embrapa Goats and Sheep). The insemination dose was $100 \times 10^{6}$ spermatozoa in $0.25 \mathrm{~mL}$ straws. In a naturally mated group of females, a buck to doe ratio was 1:6. Mucus was classified at the time 

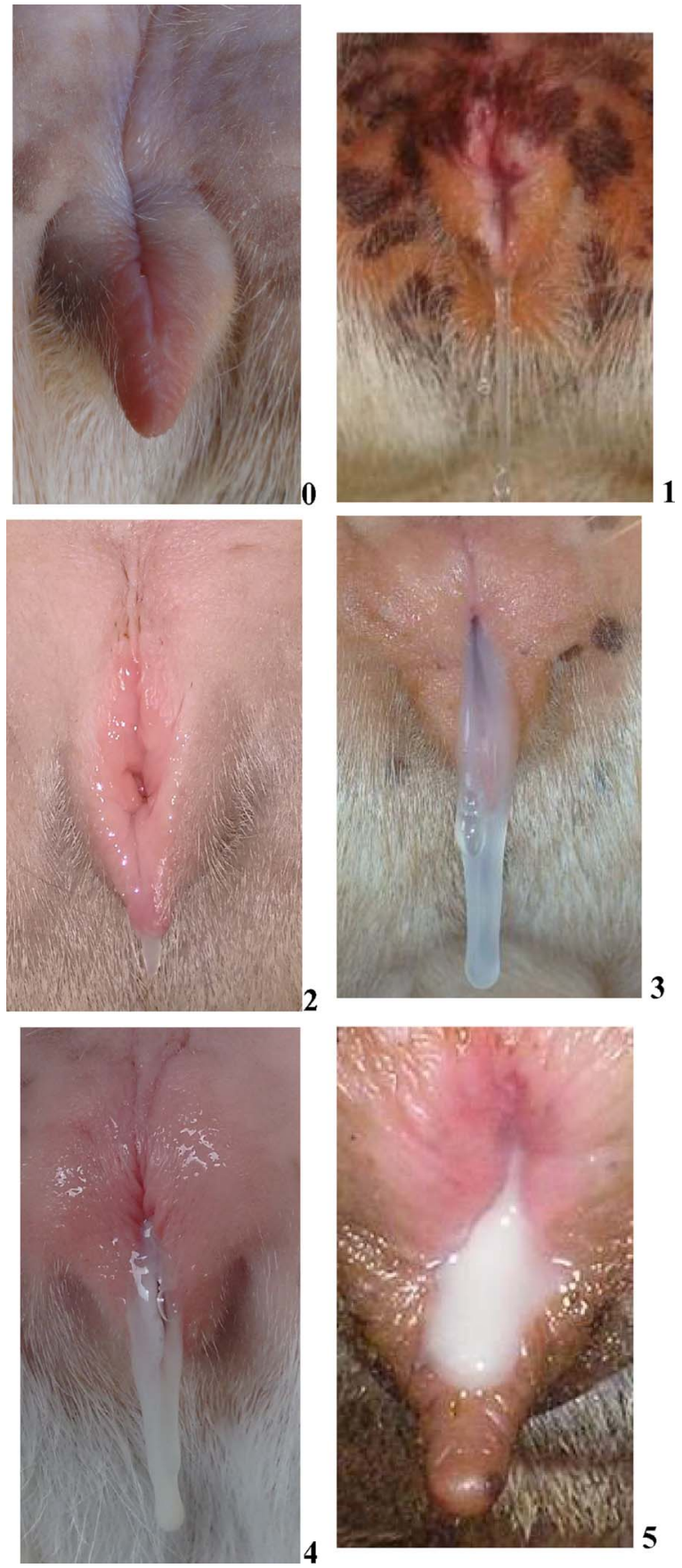

Fig. 3. Observations on the cervical mucus discharge in the vulva of the goats. 0-no discharge, no estrus; 1-crystalline mucus; 2-crystalline/striated mucus; 3-striated mucus; 4-striated/caseous mucus; and 5-caseous mucus. See the text for details of mucous categories.

of $\mathrm{AI}$ as detailed for Experiment 1 above. The conception rate was checked 30-40 d after natural mating or AI, and confirmed on day 60 of pregnancy with transrectal ultrasonography.

\subsection{Data analyses}

The following variables were recorded: i. estrous response (number of does in estrus/number of treated does $\times 100 \%$ ); ii. interval to estrus (time from sponge removal to first standing for mounting); iii. interval from the onset of estrus to the first observation of cervical mucus; iv. interval from the onset of estrus to ovulation; v. percentage of does ovulating (number of does with confirmed ovulation/number of does evaluated by ultrasonography $\times 100 \%$ ); vi. number of ovulations per doe; vii. interval from the first observation of cervical mucus to ovulation; viii. ovulatory diameter (the last measurement obtained before ovulation of all the follicles that ovulated); ix. diameter of non-ovulatory follicles (mean size of the three largest follicles detected on the day of ovulation); x. cervical mucus type (1 to 5); xi. diameter of the largest follicle identified during the entire period of cervical mucus evolution; and xii. conception rate (number of pregnant does/number of does mated or inseminated $\times 100 \%)$.

Statistical tests with $\mathrm{P}<0.05$ were considered significant and were defined as tendency when $\mathrm{P}$ was between 0.05 and 0.07. Parametric variables (expressed as mean $\pm \mathrm{SD}$ ) were subjected to one-way ANOVA and compared by Tukey test using the Bio Estat program [19]. The existence of interactions between individual input variables was also checked. Non-parametric variables were analyzed by chi-square test and Fisher exact test.

\section{Results}

\subsection{Experiment 1}

There were no interactions $(\mathrm{P}>0.05)$ between gonadotropin treatments and parity/lactation status for any of the variables studied. Estrus behavior and ovarian responses in the estrous-induced goats according are shown in Table 1 . All females exhibiting behavioral estrus ovulated. It is noteworthy that out of seven goats that ovulated in hCG group, in six animals, ovulations occurred between 60 and $72 \mathrm{~h}$ after sponge removal, contributing to a high incidence of ovulations during that period.

Data analyzed according to physiological status of experimental animals (parity/lactation) are presented in Table 2. The onset of estrus and ovulations after sponge removal tended to occur earlier in nulliparous than in multiparous does.

Female that were not in estrus had closed cervical lumen, as well as pale and dry cervical and vaginal walls whereas during the estrous phase, the cervix is open with abundant mucus flowing into the vagina, and cervical and vaginal walls were hyperemic and swollen (Fig. 2). The vulva also appeared dry in pre-estrous goats while it appeared wet in the goats in estrus (Fig. 3). Temporal relationships among the onset of estrus, timing of ovulations and changes in the type of cervical mucus are summarized in Table 3. Crystalline mucus appeared to be the first marker of estrus, showing before the first acceptance of the mounting as indicated by negative correlation values. Subsequently, cervical mucus undergoes changes from onset of estrus to the end of the estrous and ovulation. These changes in the type of mucus secretion were associated with the changes in the mean diameter of the largest follicle identified during the entire period of cervical mucus evaluation (Table 4).

Percentages of ovulating animals that had exhibited different characteristics of cervical mucus are reported in Table 5. Specific changes in the appearance of cervical mucus were indicative of impending ovulations and striated/caseous mucus was the evident marker of ovulation in the goats of the present study.

\subsection{Experiment 2}

There was no difference $(\mathrm{P}>0.05)$ among the breeds in any of the variables studied and so the data for all animals were pooled. Reproductive outcomes analyzed did not vary $(\mathrm{P}>0.05)$ among different gonadotropin treatments (Table 6). At AI, semen was deposited at the cervical opening (no passage) in $9.1 \%(2 / 22)$ of goats, into the cervix in $4.5 \%(1 / 22)$, and into the uterus in $86.4 \%(19 / 22)$ of animals. Only intrauterine AI resulted in pregnancies $(57.9 \%$ or $11 / 19)$. Two goats had cervical mucus categorized as type 2 - crystalline/striated (9.1\%), four goats had mucus type 3 - striated (18.2\%) and 16 goats had mucus type $4-$ striated/caseous $(72.7 \%)$. Conception rate was $0.0 \%(0 / 2), 25.0 \%(1 / 4)$ and $62.5 \%(10 / 16)$ for the goats with cervical 
Table 1

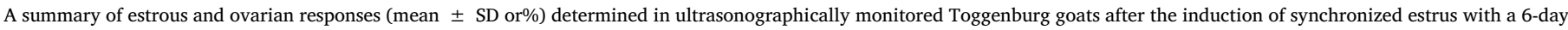
progestagen treatment with d-cloprostenol and different gonadotropins administration $24 \mathrm{~h}$ before sponge removal (Experiment 1).

\begin{tabular}{|c|c|c|c|c|}
\hline \multirow[t]{2}{*}{ Parameter } & \multicolumn{4}{|c|}{ Dose and type of gonadotropin } \\
\hline & $20 \mathrm{IU}$ FSH & $200 \mathrm{IU}$ eCG & 250 IU hCG & Overall \\
\hline Estrous response (\%) & $50.0(4 / 8)$ & $100.0(8 / 8)$ & $87.5(7 / 8)$ & $79.2(19 / 24)$ \\
\hline Interval from sponge removal to the onset of estrus (h) & $\begin{array}{l}56.0 \pm 19.6^{\mathrm{a}} \\
{[32-72]}\end{array}$ & $\begin{array}{l}43.0 \pm 20.5^{\mathrm{ab}} \\
{[24-72]}\end{array}$ & $\begin{array}{l}30.9 \pm 8.6^{b} \\
{[24-48]}\end{array}$ & $41.3 \pm 18.5$ \\
\hline Interval from sponge removal to ovulation (h) & $\begin{array}{l}93.5 \pm 30.3 \\
{[59-129]}\end{array}$ & $\begin{array}{l}72.7 \pm 19.9 \\
{[51-99]}\end{array}$ & $\begin{array}{l}63.1 \pm 19.1 \\
{[51-106]}\end{array}$ & $73.5 \pm 23.7$ \\
\hline Interval from the onset of estrus to ovulation (h) & $\begin{array}{l}37.5 \pm 13.3 \\
{[27-57]}\end{array}$ & $\begin{array}{l}29.7 \pm 5.8 \\
{[27-43]}\end{array}$ & $\begin{array}{l}32.2 \pm 11.6 \\
{[27-58]}\end{array}$ & $32.3 \pm 9.8$ \\
\hline Ovulatory diameter $(\mathrm{mm})^{\dagger}$ & $\begin{array}{l}6.8 \pm 0.6 \\
{[5.9-8.6]}\end{array}$ & $\begin{array}{l}7.2 \pm 0.8 \\
{[6.2-9.3]}\end{array}$ & $\begin{array}{l}7.3 \pm 0.9 \\
{[6.2-9.8]}\end{array}$ & $7.2 \pm 0.8$ \\
\hline Diameter of non-ovulatory follicles $(\mathrm{mm})^{t}$ & $\begin{array}{l}4.7 \pm 1.2 \\
{[3.4-5.8]}\end{array}$ & $\begin{array}{l}4.6 \pm 0.7 \\
{[3.2-5.0]}\end{array}$ & $\begin{array}{l}4.6 \pm 0.8 \\
{[3.3-5.9]}\end{array}$ & $4.6 \pm 0.8$ \\
\hline Number of ovulations & $\begin{array}{l}2.0 \pm 0.8 \\
{[1-3]}\end{array}$ & $\begin{array}{l}1.4 \pm 0.5 \\
{[1-2]}\end{array}$ & $\begin{array}{l}1.6 \pm 0.8 \\
{[1-3]}\end{array}$ & $1.6 \pm 0.7$ \\
\hline
\end{tabular}

${ }^{\mathrm{a}, \mathrm{b}}$ Means with different superscripts within rows differed (Tukey test, $\mathrm{P}<0.05$ ). () Number of animals; [] Ranges.

${ }^{\dagger}$ The last measurement obtained before ovulation of all the follicles that ovulated.

* Diameter of non-ovulatory follicles (mean size of the three largest follicles detected on the day of ovulation).

mucus crystalline/striated, striated, and striated/caseous, respectively $(\mathrm{P}>0.05)$.

\section{Discussion}

The interval from progestagen treatment to the onset of estrus in Experiment 1 was shorter in hCG treated goats compared with the pFSH group, whereas the timing of estrous onset in the females receiving eCG was intermediate. However, the difference between the hCG and pFSH treatments was not observed when a greater number of animals was used (Experiment 2). The estrous response rate was on average $79.2 \%$ $(19 / 24)$ and $92.5 \%$ (74/80) in Experiment 1 and 2, respectively. These values are similar to those reported in previous studies in Toggenburg goats under similar environmental conditions (87\% [16] and 95\% [14]) that received eCG for estrous induction. Similarly, Fonseca et al. [2] obtained $95 \%$ or $75 \%$ of estrous response in goats after eCG or hCG treatments, respectively, following short-term (6-day) progesterone treatments and using a lower dose $(22.5 \mu \mathrm{g})$ of d-cloprostenol than in the present study $(30 \mu \mathrm{g})$.

The interval to estrus averaged 41 and $46 \mathrm{~h}$ after the end of progestagen priming in Experiment 1 and 2, respectively. The interval to estrus is an important parameter in developing the protocols for timed
Table 3

Intervals (mean \pm SD) from first detection of different cervical mucus types to the onset of behavioral estrus or ovulation time in Toggenburg goats subjected to the estrous induction protocols with a 6-day progestagen treatment plus d-cloprostenol and different gonadotropins administered $24 \mathrm{~h}$ before sponge removal (Experiment 1 ).

\begin{tabular}{lll}
\hline \multirow{2}{*}{ Cervical mucus (types) } & \multicolumn{2}{l}{ Time (hours) } \\
\cline { 2 - 3 } & Estrous onset & Ovulation time \\
\hline Crystalline (1) & $-9.6 \pm 10.5$ & $-44.8 \pm 16.9$ \\
Crystalline/striated (2) & $-2.0 \pm 8.0$ & $-34.8 \pm 1.5$ \\
Striated (3) & $13.9 \pm 7.7$ & $-18.5 \pm 7.7$ \\
Striated/caseous (4) & $30.0 \pm 10.3$ & $-1.9 \pm 6.8$ \\
Caseous (5) & $41.3 \pm 14.6$ & $9.1 \pm 9.8$ \\
\hline
\end{tabular}

The negative values indicate that the specific type of cervical mucus was observed before the onset of estrus or ovulation. $\mathrm{P}>0.05$.

AI. These intervals were shorter than $53 \mathrm{~h}$ obtained in the Boer breed [20], greater than the 33-h interval observed in dairy goats [21], and similar to that in Toggenburg goats $(46 \mathrm{~h})$ subjected to a short-term estrous induction treatment [16]. Baril et al. [21] used 400-600 IU of eCG, which presumably promoted higher ovarian follicular activity and shortened the time to estrus. However, these eCG doses could result in a

Table 2

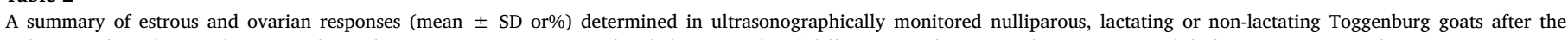
induction of synchronized estrus with a 6-day progestagen treatment plus d-cloprostenol and different gonadotropins administration $24 \mathrm{~h}$ before sponge removal (Experiment 2 ).

\begin{tabular}{|c|c|c|c|c|}
\hline \multirow[t]{2}{*}{ Parameter } & \multicolumn{4}{|c|}{ Physiological status } \\
\hline & Nulliparous & Lactating & Non-lactating & Overall \\
\hline Estrous response (\%) & $66.7(6 / 9)$ & $88.9(8 / 9)$ & $83.3(5 / 6)$ & $79.2(19 / 24)$ \\
\hline Interval from sponge removal to the onset of estrus (h) & $\begin{array}{l}28.0 \pm 4.4^{B} \\
{[24-32]}\end{array}$ & $\begin{array}{l}47.0 \pm 17.9^{\mathrm{AB}} \\
{[24-72]}\end{array}$ & $\begin{array}{l}48.0 \pm 24.0^{\mathrm{A}} \\
{[24-72]}\end{array}$ & $41.3 \pm 18.5$ \\
\hline Interval from sponge removal to ovulation (h) & $\begin{array}{l}57.8 \pm 9.2^{\mathrm{B}} \\
{[51-67]}\end{array}$ & $\begin{array}{l}76.7 \pm 18.5^{\mathrm{A}} \\
{[58-105]}\end{array}$ & $\begin{array}{l}87.5 \pm 34.4^{\mathrm{A}} \\
{[52-129]}\end{array}$ & $73.5 \pm 23.7$ \\
\hline Interval from the onset of estrus to ovulation (h) & $\begin{array}{l}29.8 \pm 6.5 \\
{[27-43]}\end{array}$ & $\begin{array}{l}29.7 \pm 4.0 \\
{[26-34]}\end{array}$ & $\begin{array}{l}39.5 \pm 16.3 \\
{[27-57]}\end{array}$ & $32.3 \pm 9.8$ \\
\hline Ovulatory diameter $(\mathrm{mm})^{\dagger}$ & $\begin{array}{l}6.9 \pm 1.1 \\
{[5.9-8.4]}\end{array}$ & $\begin{array}{l}7.2 \pm 0.6 \\
{[6.3-8.8]}\end{array}$ & $\begin{array}{l}7.3 \pm 0.7 \\
{[6.4-9.8]}\end{array}$ & $7.2 \pm 0.8$ \\
\hline Diameter of non-ovulatory follicles (mm) & $\begin{array}{l}3.9 \pm 0.5^{b} \\
{[3.0-5.9]}\end{array}$ & $\begin{array}{l}5.1 \pm 0.7^{\mathrm{a}} \\
{[3.2-6.0]}\end{array}$ & $\begin{array}{l}4.6 \pm 0.8^{\mathrm{ab}} \\
{[3.9-5.9]}\end{array}$ & $4.6 \pm 0.8$ \\
\hline Number of ovulations & $\begin{array}{l}1.2 \pm 0.4 \\
{[1-2]}\end{array}$ & $\begin{array}{l}1.6 \pm 0.7 \\
{[1-3]}\end{array}$ & $\begin{array}{l}2.0 \pm 0.7 \\
{[1-3]}\end{array}$ & $1.6 \pm 0.7$ \\
\hline
\end{tabular}

Means with different superscripts within rows differed at $\mathrm{P}<0.05\left(^{\mathrm{a}, \mathrm{b}}\right)$ or at $P \geq 0.05$ and $<0.07$ ( ${ }^{\mathrm{A}, \mathrm{B}}$, tendency) (Tukey test). () Number of animals; [] Ranges.

$\uparrow$ The last measurement obtained before ovulation of all the follicles that ovulated.

* Diameter of non-ovulatory follicles (mean size of the three largest follicles detected on the day of ovulation). 
Table 4

Diameters of preovulatory follicle (mean $\pm \mathrm{SD} ; \mathrm{mm}$ ) according to the cervical mucus types observed in Toggenburg goats subjected to the estrous induction protocols with a 6day progestagen treatment plus d-cloprostenol and different gonadotropins administered $24 \mathrm{~h}$ before sponge removal (Experiment 1).

\begin{tabular}{lllll}
\hline \multirow{2}{*}{ Cervical mucus (types) } & \multicolumn{4}{l}{ Dose and type of gonadotropin } \\
\cline { 2 - 5 } & 20 IU FSH & 200 IU eCG & 250 IU hCG & Overall \\
\hline Crystalline (1) & $5.9 \pm 2.7$ & $7.0 \pm 1.1$ & $6.7 \pm 1.5$ & $6.7 \pm 1.4^{\mathrm{a}}$ \\
Crystalline/striated (2) & $6.9 \pm 0.8$ & $7.1 \pm 1.2$ & $7.6 \pm 1.3$ & $7.2 \pm 1.1^{\mathrm{a}}$ \\
Striated (3) & $6.6 \pm 1.9$ & $7.1 \pm 1.1$ & $7.8 \pm 1.3$ & $7.3 \pm 1.3^{\mathrm{a}}$ \\
Striated/caseous (4) & $6.1 \pm 1.2$ & $4.8 \pm 1.4$ & $5.4 \pm 1.5$ & $5.3 \pm 1.4^{\mathrm{b}}$ \\
Caseous (5) & $5.5 \pm 0.3$ & $4.0 \pm 1.3$ & $4.4 \pm 1.0$ & $4.4 \pm 1.1^{\mathrm{b}}$ \\
\hline
\end{tabular}

${ }^{\mathrm{a}, \mathrm{b}}$ Means within columns with different superscripts differed (Tukey test, $\mathrm{P}<0.05$ ).

Table 5

Percentages of animals ovulating according to different characteristics of cervical mucus in Toggenburg goats subjected to the estrous induction protocols with a 6-day progestagen treatment plus d-cloprostenol and different gonadotropins administered $24 \mathrm{~h}$ before sponge removal (Experiment 1).

\begin{tabular}{lllll}
\hline Cervical mucus (types) & \multicolumn{4}{l}{ Dose and type of gonadotropin } \\
\cline { 2 - 5 } & $\begin{array}{l}20 \mathrm{IU} \\
\text { FSH }\end{array}$ & $\begin{array}{l}\text { 200 IU } \\
\text { eCG }\end{array}$ & $\begin{array}{l}250 \mathrm{IU} \\
\text { hCG }\end{array}$ & Overall \\
\hline $\begin{array}{c}\text { Crystalline/striated to } \\
\text { striated }\end{array}$ & $\begin{array}{l}25.0(1 / \\
4)\end{array}$ & $0.0(0 / 7)$ & $42.9(3 / 7)$ & $22.2^{\mathrm{a}}(4 / 18)$ \\
$\begin{array}{c}\text { Striated to striated/ } \\
\text { caseous }\end{array}$ & $\begin{array}{l}75.0(3 / \\
4)\end{array}$ & $85.7(6 / 7)$ & $57.1(4 / 7)$ & $72.2^{\mathrm{b}}(13 / 18)$ \\
$\begin{array}{c}\text { Striated/caseous to } \\
\text { caseous }\end{array}$ & $0.0(0 / 4)$ & $14.3(1 / 7)$ & $0.0(0 / 7)$ & $5.6^{\mathrm{a}}(1 / 18)$ \\
\hline
\end{tabular}

() Number of animals. ${ }^{\mathrm{a}, \mathrm{b}}$ Percentages with different superscripts within columns differed (Fisher exact test, $\mathrm{P}<0.05)$.

Table 6

Reproductive efficiency (mean \pm SD or\%) of artificially inseminated (AI) or naturally mated (NM) dairy goats subjected to the estrous induction protocols with a 6-day progestagen treatment plus d-cloprostenol and different gonadotropins administered $24 \mathrm{~h}$ before sponge removal (Experiment 2).

\begin{tabular}{lllll}
\hline Parameter & \multicolumn{2}{l}{ Dose and type of gonadotropin } & & \\
\cline { 2 - 5 } & 20 IU FSH & 200 IU eCG & 250 IU hCG & Overall \\
\hline $\begin{array}{c}\text { Estrous response } \\
(\%)\end{array}$ & $88.5(23 / 26)$ & $92.6(25 / 27)$ & $96.3(26 / 27)$ & $92.5(74 / 80)$ \\
$\begin{array}{c}\text { Interval from the } \\
\text { sponge } \\
\text { removal to the } \\
\text { onset of estrus } \\
\text { (h) }\end{array}$ & $46.9 \pm 13.8$ & $44.6 \pm 17.5$ & $48.0 \pm 20.9$ & $46.5 \pm 17.7$ \\
$\begin{array}{c}\text { Conception rate } \\
\text { after AI (\%) }\end{array}$ & $42.9(3 / 7)$ & $42.9(3 / 7)$ & $62.5(5 / 8)$ & $50.0(11 / 22)$ \\
$\begin{array}{c}\text { Conception rate } \\
\text { after NM (\%) }\end{array}$ & $56.2(9 / 16)$ & $83.3(15 / 18)$ & $55.5(10 / 18)$ & $65.4(34 / 52)$ \\
\hline
\end{tabular}

() Number of animals. $\mathrm{P}>0.05$.

greater number of offspring and/or embryo mortality and so the eCG doses exceeding $400 \mathrm{IU}$ are generally not recommended for goats raised under the Brazilian tropical conditions [22].

In the present study, all does showing the signs of estrus in Experiment 1 ovulated, with an overall ovulation rate of $79 \%(19 / 24)$. A similar percentage (80\%) was reported in the Alpine breed [23]. The number of ovulations averaged 1.6/doe, similar to that previously reported in Toggenburg goats (1.7) [14]. A dose of 20 IU of pFSH appeared to be sufficient for inducing ovulation without promoting superovulatory responses in goats.

Based on the observations on the ovulatory follicular dynamics in the goats of the present study, we can confirm that a single treatment with hCG or pFSH was adequate to support the growth of antral follicles in goats during the non-breeding season and it is therefore a viable option to substitute eCG in estrous synchronization protocols. This was expected since both of these gonadotropins, although possessing somewhat different activity and half-life, act directly to stimulate antral follicular growth. Clearly, the use of exogenous gonadotropins is necessary for estrous induction in the females that are in anoestrus due to lactation, nutritional status or seasonality. In southeastern Brazil, the vast majority of small ruminants are in anestrus at the time of the year in which this study was carried out (September to October; [15]). However, in the present study we did not confirm if all of the goats were anestrous prior to the commencement of presently tested estrous induction protocols; since it is possible that some females had been cycling, we consistently used the luteolytic doses of PGF2 $\alpha$ in our synchronization protocols.

One of the most compelling reasons to replace eCG in animal breeding protocols is the production of anti-eCG antibodies and a consequent reduction in its efficiency [4]. However, the possibility of synthesizing anti-hCG and anti-pFSH antibodies after successive treatments should not be ignored either [24]. Immunization of animals with xenogenic polypeptide, protein or glycoprotein hormones has been well described; nevertheless, it is necessary to further research on immunological consequences of treatments with hCG and pFSH in goats. It is also possible that using different gonadotropins for the control of the estrous cycle in the same groups of animals may contribute to improved reproductive efficiency throughout the female reproductive life.

In the present study, nulliparous and multiparous goats exhibited distinctive estrous behavior. Differences in the duration of the interval from progestagen treatment to estrus and ovulation may necessitate different breeding strategies, especially when $\mathrm{AI}$ is applied. An interval of $55 \mathrm{~h}$ after sponge removal in short-term estrous induction protocols is commonly recommended as an ideal time for fixed-time AI in Brazilian tropical conditions; however, it may have to be altered when nulliparous goats are used. Constant monitoring of estrous behavior and AI performed relative to the timing of estrus could result in significantly better conception rates in goats. This notion is logical since the interval from the onset of estrus to ovulation does not seem to be strongly influenced by the physiological status and parity of goats.

Examinations of the cervical mucus to determine its quantity and physical characteristics are used to predict the timing of ovulation in women [25]; however, this method has not yet been extensively explored in animal reproduction. In the present study, the first type of cervical mucus observed was crystalline. It appeared even before the period of standing heat (sexual receptivity) in the pro-estrous phase, when females were actively seeking males and displayed tail flagging, but disallowing the mounting and copulation [26]. Animals with cervical mucus categorized as crystalline to striated types had larger antral follicles compared with animals with the striated/caseous and caseous types of cervical mucus. This may indicate that the majority of ovulations occur during the secretion of striated/caseous mucus, since the reduction in diameter of preovulatory follicles typically occurs just before follicle rupture (i.e. ovulation) in small ruminants [15].

Evolution of cervical mucus can be performed when the cervical os is observed with the speculum inserted into the vagina, as described earlier [18]. The evaluation of mucus present in the vulva can also be accomplished. The ease with which the examination of cervical mucus could be accomplished makes it and an extremely useful method for determining the optimal time AI procedures. This method can potentially be applied to different types of semen used (i.e., fresh, refrigerated or frozen-thawed semen) as different semen storage and preservation techniques impinge on the time required acquire full fertilizing ability (i.e., sperm capacitation) and also its transport/survival time in the reproductive tract of the female.

Using transcervical AI (a.k.a. insemination through the cervical immobilization) [18], Siqueira et al. [13] inseminated synchronized Toggenburg goats with cooled semen approximately $20 \mathrm{~h}$ after estrous detection and reported the higher conception rate (58\%) when goats 
had striated mucus compared with only $15 \%$ when they were inseminated at the time of excreting crystalline (1) cervical mucus. In the present study, the interval from the first detection of mucus to ovulation was around $45 \mathrm{~h}$; in ruminant species, an estimated period of sperm survival in the female reproductive tract is up to $48 \mathrm{~h}$ [27]. Clearly, the timed AI performed between 12 and $16 \mathrm{~h}$ after estrous detection does not guarantee that the procedure is done at the optimal time interval relative to ovulation. Vallet and Baril [28] reported reduced numbers of cleaved eggs when AI was performed $<12 \mathrm{~h}(22.0 \%)$ or $>32 \mathrm{~h}$ (29.6\%) after the onset of estrus in superovulated dairy goats. On the other hand, Aisen et al. [29] reported the 80, 60 and 25\% pregnancy rates when ewes were artificially inseminated with fresh semen at the time when cervical mucus classified as crystalline, striated or caseous, respectively.

The onset of induced/synchronized estrus could be highly variable, not being a consistent parameter to establish the optimal time to perform the insemination. We believe that the observation of changes in cervical mucus could be a very useful and reliable tool to indicate the optimal time for AI. Considering the similarity between the intervals "from the onset of estrus to ovulation" $(\sim 32 \mathrm{~h})$ and "from the onset of estrus to the time of excreting type 4 (striated/caseous) cervical mucus" $(\sim 30 \mathrm{~h})$, it can be concluded that type 4 mucus can be detected at or around the time of ovulation. It is reasonable to suggest that the most appropriate time to perform AI using frozen-thawed semen is when the goats secrete type 4 mucus (striated/caseous) or at least type 3 mucus (striated), the diameter of the cervical os opening appeared to be more expanded and perhaps facilitating cervical transposing/intrauterine insemination. The results of the present study are supportive of this association because in these conditions, goats inseminated $22-24 \mathrm{~h}$ after the onset of estrus had $72.7 \%$ of striated/caseous mucus and AI efficiency resulted in $86.4 \%$ of intrauterine insemination and $62.5 \%$ of conception rate. In accordance with the former supposition, it is feasible that the insemination of goats presenting mucus type 1 or 2 (crystalline or crystalline/striated) or type 5 (caseous) would probably result in very low conception rates. Even though the practical applications of the timing of the estrous onset and various characteristics of cervical mucus in dairy goats require more field studies, these simple and inexpensive methods have the makings of techniques that will enhance the efficiency of $\mathrm{AI}$ in this species.

In summary, the results of this study indicate that both hCG (250 IU) and pFSH (20 IU) may be considered as a substitute for eCG (200 IU) in seasonally anestrous dairy goats subjected to the hormonal estrous induction protocols. More research is needed to evaluate the potential effects of varying doses of all gonadotropins. This study also provides important practical information on temporal associations between the changes in cervical mucus characteristics, ovarian follicle development, and the timing of ovulation during estrous synchronization in anovular dairy goats that can potentially be used to improve the outcome of AI.

\section{Conflict of interest}

The authors declare that they have no conflict of interest.

\section{Acknowledgments}

The authors wish to thank Dr. Marlene Bruschi from the Granja Água Limpa Farm, Piau, Minas Gerais, Brazil for providing and housing the animals employed in this study. This study was supported by the National Council for Scientific and Technological Development (CNPq; Projects 559151/2010-1 and 310166/2012-8) and Brazilian Agriculture Research Corporation (EMBRAPA; Project 02.08.02.005.00.04). FZ Brandão and MEF Oliveira are fellows of the CNPq and JMGSF of CAPES.

\section{References}

[1] Abecia JA, Forcada F, González-Bulnes A. Hormonal control of reproduction in small ruminants. Anim Reprod Sci 2012;130:173-9.

[2] Fonseca JF, Bruschi JH, Zambrini FN, Demczuk E, Viana JHM, Palhão MP. Induction of synchronized estrus in dairy goats with different gonadotropins. Anim Reprod 2005;2:50-3.

[3] Simões J. Recent advances on synchronization of ovulation in goats, out of season, for a more sustainable production. Asian Pac J Reprod 2015;4:157-65.

[4] Baril G, Remy B, Leboeuf B, Beckers JF, Saumande J. Synchronization of estrus in goats: the relationship between eCG binding in plasma, time of occurrence of estrus and fertility following artificial insemination. Theriogenology 1996;45:1553-9.

[5] Hervé V, Roy F, Bertin J, Guillou F, Maurel MC. Anti-equine chorionic gonadotropin (eCG) antibodies generated in goats treated with eCG for the induction of ovulation modulate the luteinizing hormone and follicle-stimulating hormone bioactivities of eCG differently. Endocrinology 2004;145:294-303.

[6] De Rensis F, López-Gatius F, García-Ispierto I, Techakumpu M. Clinical use of human chorionic gonadotropin in dairy cows: an update. Theriogenology 2010;73:1001-8.

[7] Saleh M, Shahin M, Wuttke W, Gauly M, Holtz W. Pharmacokinetics of human chorionic gonadotropin (hCG) after intramuscular administration in goats (Capra hircus). Reproduction 2012;144:77-81.

[8] Kawate N, Yamazaki M, Tamada H, Inaba T, Sawada T. Effect of low dose of hCG on induction of fertile estrus in Shiba goats pretreated intravaginally with progesterone during the early postpartum nursing period. J Reprod Devel 2002;48:487-504.

[9] Navanukraw C, Khanthusaeng V, Kraisoon A, Uriyapongson S. Estrous and ovulatory responses following cervical artificial insemination in Thai-native goats given a new or once-used controlled internal drug release with human chorionic gonadotropin. Trop Anim Health Prod 2014;46:1441-6.

[10] Akbar AM, Nett TM, Niswender GD. Metabolic clearance and secretion rates of gonadotropins at different stages of the estrous cycle in ewes. Endocrinology 1974;94:1318-24.

[11] Cardoso Neto BM, Barbosa LP, Aguiar CS, Souza RS, Santana ALA, Mendes CS, et al Follicle-stimulating hormone to substitute equine chorionic gonadotropin in the synchronization of ovulation in Santa Inês ewes. Rev Bras Zoo 2012;41:603-6.

[12] Knights M, Hoehn T, Lewis PE, Inskeep EK. Effectiveness of intravaginal progesterone inserts and FSH for inducing synchronized estrus and increasing lambing rate in anestrous ewes. J Anim Sci 2001;79:1120-31.

[13] Siqueira AP, Fonseca JF, Silva Filho JM, Bruschi JH, Viana JHM, Palhares MS, et al Parâmetros reprodutivos de cabras Toggenburg inseminadas com sêmen resfriado, após diluição em meio à base de gema de ovo. Arq Bras Med Vet Zootec 2009;61:299-305.

[14] Souza JMG, Torre CAA, ALRS Maia, Brandão FZ, Bruschi JH, Viana JH, et al. Autoclaved, previously used intravaginal progesterone devices induces estrus and ovulation in anestrous Toggenburg goats. Anim Reprod Sci 2011;129:50-5.

[15] Oliveira MEF, Ayres H, Oliveira LG, Barros FFPC, Oba E, Bicudo SD, et al. Vicente WRR. Effects of season and ovarian status on the outcome of long-term progesterone-based estrus synchronization protocols and ovulatory follicle development in Santa Inês ewes under subtropical conditions. Theriogenology 2016;85:452-60.

[16] Fonseca JF, Bruschi JH, Santos ICC, Viana JHM, Magalhães ACM. Induction of estrus in non-lactating dairy goats with different estrous synchrony protocols. Anim Reprod Sci 2005;85:117-24.

[17] Ginther OJ, Kot K. Follicular dynamics during the ovulatory season in goats. Theriogenology 1994;42:987-1001.

[18] Fonseca JF, Alvim GP, Souza-Fabjan JMG, Oliveira MEF, Brair VL, Brandão FZ, et al. Reproductive features and use of an anti-inflammatory drug in estrus-induced dairy goats artificially inseminated in a standing position with cervix immobilization. Reprod Biol 2017;17:268-73.

[19] Ayres M, Ayres Jr M, Ayres DL, Santos AS. BioEstat 2.0, Aplicações estatísticas nas áreas das ciências biológicas e médicas. Belém: Sociedade Civil Mamirauá; 2000.

[20] Greyling JPC, Van der Nest M. Synchronization of oestrus in goats: dose effect of progestagen. Small Rumin Res 2000;36:201-7.

[21] Baril G, Leboeuf B, Saumande J. Synchronization of estrus in goats: the relationship between time of occurrence of estrus and fertility following artificial insemination. Theriogenology 1993;49:621-8.

[22] Espeschit CJB. Sincronização do estro em cabras tratadas com progestágeno (MAP) associado à gonadotropina sérica (PMSG) e cloprostenol. (Master Thesis). Brazil: Viçosa Federal University; 1986.

[23] Fonseca JF, Souza JMG, Bruschi JH, Viana JHM, Brandão FZ, Silva WJ, et al. Induction of estrus in cyclic Alpine goats with short-term progesterone protocols with or without eCG administration. Reprod Fertil Dev 2010;22:169.

[24] Remy B, Baril G, Vallet JC, Dufour R, Chouvet C, Saumande J, et al. Are antibodies responsible for a decreased superovulatory response in goats which have been treated repeatedly with porcine follicle-stimulating hormone. Theriogenology 1991;36:389-99.

[25] Wolman I, Gal TB, Jaffa AJ. Cervical mucus status can be accurately estimated by transvaginal ultrasound during fertility evaluation. Fertil Steril 2009;92:1165-7.

[26] Oliveira RMP. Comportamento sexual de cabras Toggenburg durante a estação reprodutiva após luteólise natural ou induzida. (Master Thesis). Brazil: Minas Gerais Federal University; 2010. 223p.

[27] Hafez ESE, Hafez B, editors. Reproduction in Farm Animals. 7th ed.Baltimore: USA: Wiley; 2000.

[28] Vallet JC, Baril G. Effect of time of laparoscopic intrauterine insemination in superovulated dairy goats. Proc. 6th Scientific Meeting of European Embryo Transfer Association. 1990. p. 188-9.

[29] Aisen E, Larreguy D, Alvarez H. Parámetros relacionados con la fertilidad en la práctica de la inseminación artificial ovina por via cervical. VII Congreso Argentino de Ciencias Veterinarias. 1994. 